\title{
THE RESULTS OF STUDYING THE TECHNIQUE OF MAKING GOLDEN HORDE PRODUCTS MADE OF NON-FERROUS METALS (FROM THE COLLECTION OF THE VOLGOGRAD REGIONAL MUSEUM OF LOCAL LORE) ${ }^{1}$
}

\author{
Kseniya S. Kovaleva \\ Institute of Archaeology, RAS, Moscow, Russian Federation; \\ Volgograd State University, Volgograd, Russian Federation
}

\begin{abstract}
Introduction. The article is devoted to the results of tracing research of things made of non-ferrous metals from the collections of Tsarevskoe, Vodyanskoe, and Mechetnoe settlements, stored in the funds of the Volgograd regional museum of local lore. Method. The author used the method of tracing. The digital microscope DigiMicro 2.0. was used to record the results of observation. Analysis. The author studied 63 products and allocated two large groups: 1) cast products and 2) forged products. The study fixed the following operations for cast products: the use of open and closed molds, casting in composite forms, casting by the smelted model, by the impression, liner casting. In group 2, the following methods of forging were singled out: forming forging, punching, drawing and forging of wire, bending, drawing, twisting, hacking, cutting. Soldering was used to connect the elements. After forming, most of the products passed the subsequent processing associated with the removal of defects (primarily post-casting) and the application of decor (hammering, engraving, stamping, polishing). In addition, the decor could be formed during the creation of the mold (cast decor). Results. As a result of the study, it was noted the use of a wide range of techniques and operations with a comparative technological simplicity for most products. It was also noticed that a few things have been specially prepared for the processing, and it demonstrates the use of secondary raw materials.

Key words: Golden Horde cities, bronze casting, tracing analysis, casting, forging.

Citation. Kovaleva K.S. The Results of Studying the Technique of Making Golden Horde Products Made of Non-Ferrous Metals (from the Collection of the Volgograd Regional Museum of Local Lore). Vestnik Volgogradskogo gosudarstvennogo universiteta. Seriya 4, Istoriya. Regionovedenie. Mezhdunarodnye otnosheniya [Science Journal of Volgograd State University. History. Area Studies. International Relations], 2019, vol. 24, no. 1, pp. 61-74. (in Russian). DOI: https://doi.org/10.15688/jvolsu4.2019.1.5
\end{abstract}

\section{РЕЗУЛЬТАТЫ ИССЛЕДОВАНИЯ ТЕХНИКИ ИЗГОТОВЛЕНИЯ ЗОЛОТООРДЫНСКИХ ИЗДЕЛИЙ ИЗ ЦВЕТНЫХ МЕТАЛЛОВ (ИЗ КОЛЛЕКЦИИ ВОЛГОГРАДСКОГО ОБЛАСТНОГО КРАЕВЕДЧЕСКОГО МУЗЕЯ) ${ }^{1}$}

\section{Ксения Сергеевна Ковалева}

Институт археологии РАН, г. Москва, Российская Федерация; Волгоградский государственный университет, г. Волгоград, Российская Федерация

Аннотация. Статья посвящена результатам трасологического исследования вещей из цветных металлов из коллекций Царевского, Водянского и Мечетного городищ, хранящихся в фондах Волгоградского областного 
краеведческого музея. Были изучены 63 изделия, выделены две большие группы: 1) литые и 2) изделия, для которых основной формообразующей операцией является обработка давлением. Для литых изделий зафиксированы следующие операции: использование открытых и закрытых форм, литье в разъемные составные формы, по выплавляемой модели, по оттиску, вкладышевое литье. Во второй группе выделены такие приемы ковки, как формующая ковка, выколотка, волочение и ковка проволоки, гибка, вытяжка, скручивание, рубка, резка. Из слесарно-сборочных работ отмечена пайка. После формообразования большинство изделий прошло последующую обработку, связанную с удалением дефектов (прежде всего послелитейных) и нанесением декора (тиснение, гравировка, чеканка, полировка). Кроме того, декор мог быть сформирован во время создания самой формы (литой декор). В результате изучения было выявлено применение широкого круга приемов и операций при сравнительной технологической простоте большинства изделий. Замечено, что несколько вещей были специально подготовлены к переработке, что свидетельствует об использовании вторичного сырья.

Ключевые слова: золотоордынские города, бронзолитейное ремесло, трасологический анализ, литье, обработка давлением.

Цитирование. Ковалева К. С. Результаты исследования техники изготовления золотоордынских изделий из цветных металлов (из коллекции Волгоградского областного краеведческого музея) // Вестник Волгоградского государственного университета. Серия 4, История. Регионоведение. Международные отношения. 2019. - T. 24, № 1. - C. 61-74. - DOI: https://doi.org/10.15688/jvolsu4.2019.1.5

Введение. В фондах Волгоградского областного краеведческого музея хранятся коллекции из раскопок Царевского, Водянского и Мечетного городищ. Эти известные археологические памятники на берегах Волги являются остатками крупных золотоордынских городов XIV в., появившихся в эпоху стремительного подъема градостроительства Улуса Джучи и так же быстро пришедших в упадок в результате внутриполитического конфликта и похода Тамерлана 1395 года.

Царевское городище (левый берег старого русла р. Ахтуба у с. Царев Ленинского района Волгоградская области) долгое время считалось столицей Золотой Орды. Время его появления относится к 40-м гг. XIV в., а уничтожение - к 1395 г. [1, с. 78-81]. Первые работы по изучению городища были проведены экспедицией под руководством А.В. Терещенко в 1843-1849 гг. [11]. Дальнейшее изучение памятника связано с масштабными работами Поволжской археологической экспедиции (далее ПАЭ) под руководством Г.А. Федорова-Давыдова в 1959-1968, 1971, 1973, 1994-1998 годах. В ходе этих исследований были открыты две ювелирные мастерские (вероятно, работавшие последовательно) и мастерская медника. Напротяжении 2006-2014 гг. раскопки Царевского городища велись экспедицией Волжского гуманитарного института (филиал Волгоградского государственного университета) под руководством А.А. Глухова.

Водянское городище, памятник археологии Золотой Орды (XIV в.), находится на ок- раине г. Дубовка Дубовского района Волгоградской области, на правом высоком волжском берегу. Небольшие раскопки и сборы подъемного материала проводились в 1888 и 1914 гг. членами Саратовской ученой архивной комиссии (далее - СУАК) [1, с. 51]. Экспедиция ПАЭ работала на Водянском городище в 1967-1974 годах. В 1988-1990 гг. городище исследовалось экспедицией Казанского государственного университета (далее - КГУ), а начиная с 1992 г. археологические раскопки проводит экспедиция Волгоградского государственного социально-педагогического университета (бывш. ВГПУ) под руководством Е.П. Мыськова и А.С. Лапшина.

Мечетное городище находилось на правом берегу р. Волги напротив входа в р. Ахтубу. Судя по монетным находкам, время существования города охватывает период с конца XIII по конец XIV в. [6, с. 108]. Уже к началу XX в. практически все постройки золотоордынского времени оказались разобраны, а к 1970-м гг. была осуществлена сплошная нивелировка ландшафта, что привело к утрате средневекового культурного слоя. В настоящее время бывшая территория городища почти полностью занята жилым кварталом г. Волгограда. Отдельные участки сохранились лишь вдоль береговой линии [6, c. 103]. Археологические исследования городища проводились в 1914 г. членами СУАК, в 1920 г. Ф.В. Баллодом и в 1986 г. Е.П. Мыськовым. По всей видимости, город являлся одним из крупных перевалочных пунктов торгового пути [6, с 108]. 
Коллекции раскопок этих золотоордынских городищ оказались в различных музеях. Сохранившиеся материалы раскопок А.В. Терещенко хранятся в фондах Государственного Эрмитажа и Государственного исторического музея; материалы исследований СУАК предположительно находятся в Саратовском областном музее краеведения; материалы раскопок А.А. Глухова, Е.П. Мыськова, А.С. Лапшина - в Волгоградском областном краеведческом музее (далее - ВОКМ). Материалы раскопок ПАЭ на Водянском и Царевском городищах переданы в Государственный исторический музей, Музей археологии МГУ, Археологический музей КГУ (нын. КФУ) и ВОКМ.

Таким образом, Волгоградский краеведческий музей хранит коллекции изделий из цветных металлов, полученных в результате исследований Поволжской археологической экспедицией Царевского и Водянского городищ (частично), а также полностью коллекции из Царевского городища из раскопок А.А. Глухова, Водянского городища - из раскопок Е.П. Мыськова и А.С. Лапшина, Мечетного городища из сборов Е.П. Мыськова ${ }^{2}$. На данный момент коллекция исследована не полностью.

Методы. Для изучения технологии изготовления изделий из цветного металла использовался трасологический метод, предполагающий визуальный анализ поверхности предметов с целью фиксации следов технических (технологических) операций ${ }^{3}$. Исследование выполнялось в музейных условиях с использованием мобильного цифрового микроскопа DigiMicro 2.0 для документации результатов наблюдений ${ }^{4}$. Фотографии сделаны с трехкратным увеличением.

Анализ. Данная статья посвящена результатам трасологического анализа вещей, хранящихся в Волгоградском областном краеведческом музее. На данном этапе мы ограничились только неразрушающими методами исследования. Коллекция из 63 предметов представлена различными украшениями, предметами фурнитуры и мелкими хозяйственными вещами (см. табл. 1, кат. 1-63; рис. ${ }^{5}$ ).

Все изученные предметы по технике изготовления делятся на две группы: 1) литые предметы и 2) изделия, для которых основной формообразующей операцией, по результатам трасологического анализа, является ковка.
Группа 1 представлена браслетами, наконечниками ремней, пуговицами, кольцом, пряжками, перстнями, бляшкой, обоймами, нательным крестом, грузиком, зеркалами, астрагалом и тремя изделиями, назначение которых установить не удалось.

Традиционно выделяется литье в открытые и закрытые формы [9, с. 147]. Литье в открытые формы подразумевает значительную доработку изделия, так как отливка получается неровной и ноздреватой. Судя по зафиксированным следам доработки поверхности (сильная заполированность) и остаткам газовых пор на поверхности, можно предположить, что одно из зеркал (кат. 45) было отлито в открытой форме.

Закрытые формы могли быть разъемными и неразъемными. Разъемные составные литейные формы (то есть состоящие из нескольких створок) использовались для изготовления таких изделий, как наконечники ремней (кат. 2, 60), пряжки (кат. 6, 50), перстни (кат. 8, 12, 49), бляшка (кат. 10), зеркала (кат. 30, 32, 35-37, 39-47) и предмет неясного назначения (кат. 63). Об использовании составных литейных форм свидетельствуют наличие литейных швов (шинка перстня, кат. 49) и следы зачистки литейной поверхности на месте расположения литейного шва (браслет, кат. 1 ; наконечник ремня, кат. 2; кольцо, кат. 4; пряжка, кат. 6; пряжка, кат. 34).

Три изделия были отлиты в неразъемную форму с использованием выплавляемой модели. О применении моделирования свидетельствуют наличие характерных складок, появившихся в процессе лепки по воску на ушке бляшки (кат. 10), и отсутствие литейных швов на коническом изделии (кат. 56). Модель для одного из изделий, предположительно фибулы (кат. 59), была выполнена из скрученных в узел вощенных нитей.

Литье по оттиску являлось самым простым способом, позволяющим тиражировать вещи, однако в таком случае конечные изделия становились более грубыми по сравнению с оригиналом. Этот способ активно применяли для изготовления зеркал. Однозначно можно сказать, что оттиском были созданы литейные формы для семи зеркал в изучаемой коллекции (кат. 32, 41-45, 47). Также с помощью оттиска были сделаны формы для нако- 
нечника ремня (кат. 2), бляшки (кат. 10), нательного креста (кат. 21) и астрагала (кат. 52). Об этом свидетельствует смазанный рельеф основных частей (рис. 2, $a, \sigma$ ).

Для формирования ушков для подвешивания (обойма, кат. 57) и шинок перстней (кат. 8, $12,49)$ использовались вкладыши в литейную форму (метод литья со вставным стержнем).

В исследуемой выборке зафиксировано два варианта изготовления штифтов бляшек отливка вместе с изделием (кат. 60) и вставка изготовленных отдельно штифтов в литейную форму (кат. 10).

Зачастую литье являлось основной формообразующей операцией, но затем изделия могли дорабатываться различными приемами ковки. Минимальная послелитейная обработка включает в себя обрубку литника (кат. 2) и снятие напильником литейного шва (кат. 4, 34) (рис. 3).

Для ряда изделий литьем была выполнена только заготовка, которая потом была доработана приемами ковки. Так, литой дрот составного разъемного браслета (кат. 1) был вытянут проковкой и согнут. Крепление на одном конце, предназначенное для соединения со второй (утраченной) частью браслета, представляет собой площадку с отверстием, сформированную рубкой при помощи зубила и долота, о чем свидетельствуют ступеньки на площадке. Другой конец имеет рельефные ушки, выполненные зубилом. Доработанные зубилом лопасти зафиксированы еще на одной литой заготовке браслета (кат. 28). Для одного из перстней, заготовка которого была получена литьем (кат. 12), ковкой были доработаны края дрота так, чтобы они создавали своими раскованными площадками щиток перстня.

Группа 2 (формообразующей операцией является ковка) представлена бубенчиками, пуговицами, браслетом, обоймами, гвоздиком, посудой, пластинами, проволочными серьгами, перстнем, сюльгамой, цепочкой, накладкой, оковкой, гигиеническим набором и пятью изделиями, назначение которых установить не удается.

Формующая ковка применялась при изготовлении подавляющего большинства вещей группы 2 (кат. 14-17, 23-27, 31, 34, 38, 48, $51,53,54,58,60-62)$. Это прежде всего раз- личные пластины и изделия, в основе которых заготовки в виде пластин.

Выколоткой из листового металла изготовлены половинки бубенчика (кат. 20).

Проволока широко применялась для изготовления украшений. Она могла быть получена путем волочения или ковкой. Так, дрот сюльгамы (кат. 11), звенья цепочки (кат. 13), изделие в виде палочки с загнутыми концами (кат. 27) изготовлены методом ковки с высокими степенями обжатия. Тонкая проволока, из которой изготавливались серьги в виде знака «вопрос» (кат. 9, 58), получена путем волочения, о чем свидетельствует, прежде всего, равномерный диаметр проволок на всем ее протяжении ( $\sim 0,2$ мм и 0,05 мм).

Путем изгибания проволоки изготовлены серьги-«вопросы» (кат. 9, 58). Прием гибки кованой заготовки использован для изготовления тела и иглы сюльгамы (кат. 11), обойм (кат. 24, 31), каста и шинки перстня (кат. 61), ушков бубенчика и пуговиц (кат. 20, 38). В случае с гвоздиком-«костылем» сгибание двух полос кованого металла в форме «бантика» являлось подготовительным этапом перед проковкой (кат. 25). Гибка перед проковкой проводилась также для изготовления венчиков посуды (кат. 26, 53). Изгибанием заготовок вокруг оправы, форму которой они принимают, изготовлена цепочка (кат. 13). Оправой в данном случае выступают сами звенья, когда в сформированное кованое звено продевается следующий дрот, сгибается на нем и т. д. Отдельной категорией вещей, подвергаемых гибке, является лом, который таким способом готовился к переплавке (кат. 15-17).

Вытяжка применяется для увеличения длины заготовки за счет уменьшения ее поперечного сечения, когда из толстого куска металла отковывается полоса или прут различного сечения [12, с. 100]. Вытяжкой изготовлены кольцо сюльгамы (кат. 11), дроты для звеньев цепочки (кат. 13), тулова чаш (кат. 26, $53)$, заготовки в виде палочек для изготовления гигиенического набора (копоушки и зубочистки) (кат. 54).

Применение скручивания, сущность которого заключается в том, что одну часть поковки поворачивают по отношению к другой под углом вокруг общей оси [12, с. 105], зафикси- 
ровано в случаях оформления концов изделий. Так, скручиванием оформлены концы сюльгамы (кат. 11) и изделия в виде палочки (кат. 27). $\mathrm{У}$ копоушки из гигиенического набора (кат. 54) скручиванием сделано ушко.

Рубка зафиксирована в 4 случаях: рубкой разделен на части дрот для изготовления звеньев цепочки (кат. 13), три изделия рубкой подготовлены для утилизации и, возможно, переплавки (кат. 14, 15, 30). О рубке свидетельствуют необработанные края с заусенцами.

В отличие от рубки, которая производится зубилом, резка ножницами или ножовкой позволяет отделять более мелкие части без оставления заусенцев. Резкой из листового металла сделаны заготовки для ушка бубенчика (кат. 20), обоймы (кат. 24, 31), заготовка для гвоздика«костыля» (кат. 25), заготовка неясного назначения (кат. 33), оковка (кат. 51), подкладка на оборотную сторону ремня в пряжке (кат. 60).

Пайкой, которая является способом неразъемного соединения металлических деталей с помощью расплавленного сплава [12, c. 220], соединены половинки бубенчика (кат. 20) и прикреплен каст к щитку перстня (кат. 61) (рис. 4, $a, \sigma$ ).

Возникшие в результате производства дефекты зачастую являются наиболее информативными свидетельствами особенностей процесса изготовления. В исследованной коллекции удалось зафиксировать прежде всего дефекты, связанные с литьем: смещение литейных створок (зеркала, кат. 46, 47; изделие, кат. 63 ), утяжину, которая получилась в результате усадки металла при затвердевании (обойма, кат. 57), и литейные поры, образовавшиеся из-за невозможности выхода скопившегося в литейной форме газа (наконечник ремня, кат. 2; пуговица, кат. 3; кольцо, кат. 4; браслет, кат. 5).

После формообразования изделие могло пройти последующую обработку, которая включает в себя удаление пороков (прежде всего послелитейных) и нанесение декора. Помимо удаленных литейных швов, упомянутых выше, были зафиксированы следы напильника, связанные с удалением литников (наконечник ремня, кат. 2) и выравниванием дефектов поверхности (пряжка, кат. 6). Декор мог наноситься на разных этапах производства, быть как литым, так и нанесенным давлением после изготовления в виде рельефных углубленных элементов [4, с. 158-159].

Литой декор мог быть вырезан на литейном ложе (браслет, кат. 5; щиток перстня, кат. 49), сформирован на восковой модели (бляшка, кат. 10; изделие, кат. 59) или оттиснут (таким способом изготовлены уже перечисленные зеркала и крест).

Декор, выполненный приемами давления, представлен тиснением по матрице (накладка, кат. 48; бубенец, кат. 62), гравировкой резцами разной глубины (пластина, кат. 7; шинка перстня, кат. 8), чеканкой. Чеканы зафиксированы с рабочей головкой разной формы: круглой (кат. 7, 20), острой (кат. 24, 51), кольцевой (кат. 23). Следы предварительной разметки отмечены дважды (кольцо, кат. 4; пластина, кат. 7).

Окончательная обработка поверхности представлена в изученной коллекции приемами полировки (кат. 29, 30, 34-37, 40-45, 48, 52).

Результаты. Исследованная выборка из 63 изделий демонстрирует применение золотоордынскими мастерами различных приемов обработки цветных металлов: литья и ковки как основных формообразующих операций, различных вариаций последующей обработки и нанесения декора. Стоит отметить наличие в сравнительно небольшой коллекции как минимум трех изделий, подготовленных к переработке, что говорит об использовании вторичного сырья и переплавке металла. В основном в коллекции представлены вещи, которые не выделяются какой-то технологической сложностью, однако это может объясняться обстоятельствами формирования коллекции Волгоградского областного краеведческого музея, когда вещи, требующие более подробного изучения, отправлялись в Москву и Казань.

На данный момент работа по технологическому изучению золотоордынских изделий из цветных металлов только начата. После обработки большого массива изделий и создания базы данных можно будет делать выводы об уровне развития цветной металлообработки городов Улуса Джучи, выделять традиционные и привнесенные технологии. Кроме того, следующий этап изучения должен включать в себя анализ химического состава сплавов. 
Каталог изделий из цветных металлов из раскопок Царевского, Водянского, Мечетного городищ (коллекция ВОКМ)

\begin{tabular}{|c|c|c|c|c|}
\hline $\begin{array}{l}\text { № } \\
\Pi / \Pi\end{array}$ & Наименование & $\begin{array}{c}\text { Шифр } \\
\text { хранения } \\
\text { ВОКМ }\end{array}$ & Происхождение & Публикации \\
\hline 1 & Браслет (фрагмент) & $24055 / 4$ & Царевское городище - 1964 & $\overline{-}$ \\
\hline 2 & Наконечник ремня & $24050 / 1$ & $\begin{array}{l}\text { Водянское городище - 1971, } \\
\text { подъемный материал }\end{array}$ & - \\
\hline 3 & Пуговица & $24050 / 2$ & $\begin{array}{l}\text { Водянское городище - 1971, } \\
\text { подъемный материал }\end{array}$ & - \\
\hline 4 & Кольцо & $24050 / 3$ & $\begin{array}{l}\text { Водянское городище - 1971, } \\
\text { подъемный материал }\end{array}$ & - \\
\hline 5 & Браслет (фрагмент) & $33747 / 3$ & $\begin{array}{l}\text { Водянское городище - 2012, } \\
\text { раскоп } 1,1-16 Б\end{array}$ & {$[8$, c. 62,209$]$} \\
\hline 6 & Пряжка & $33807 / 17$ & $\begin{array}{l}\text { Водянское городище - 2013, } \\
\text { раскоп } 1 \text {, яма } 112\end{array}$ & - \\
\hline 7 & Пластина & $9820 / 35$ н/в & $\begin{array}{l}\text { Царевское городище - 2006, } \\
\text { раскоп 2, 2-В5 }\end{array}$ & - \\
\hline 8 & Перстень с надписью & $27191 / 9$ & $\begin{array}{l}\text { Водянское городище - 1988, } \\
\text { подъемный материал }\end{array}$ & - \\
\hline 9 & $\begin{array}{l}\text { Серьга в виде знака } \\
\text { «вопрос» }\end{array}$ & $14263 / 7$ & Водянское городище - 1969 & - \\
\hline 10 & Бляшка & $33747 / 2$ & $\begin{array}{l}\text { Водянское городище - 2012, } \\
\text { раскоп } 1,1-17 \Gamma\end{array}$ & {$[8$, c. 62,209$]$} \\
\hline 11 & Сюльгама & $338071 / 6$ & $\begin{array}{l}\text { Водянское городище - 2013, } \\
\text { раскоп } 1, \text { яма } 109\end{array}$ & - \\
\hline 12 & Перстень & $24051 / 1$ & $\begin{array}{l}\text { Водянское городище - } 1969 \text {, } \\
\text { раскоп 3, 5-26 }\end{array}$ & - \\
\hline 13 & Цепочка (фрагмент) & б/и & Царевское городище - 1996 & {$[5$, c. 64$]$} \\
\hline 14 & Обрезок & б/и & $\begin{array}{l}\text { Царевское городище - 1994, } \\
\text { раскоп } 1, \text { В3-2 }\end{array}$ & {$[5$, c. 46$]$} \\
\hline 15 & Изделие (фрагмент) & б/и & $\begin{array}{l}\text { Царевское городище - 1994, } \\
\text { раскоп } 1, \text { Б9-2 }\end{array}$ & - \\
\hline 16 & Изделие & б/и & $\begin{array}{l}\text { Царевское городище - 1994, } \\
\text { раскоп 1, Б8-3 }\end{array}$ & - \\
\hline 17 & Изделие (фрагмент) & б/и & $\begin{array}{l}\text { Царевское городище - 1994, } \\
\text { раскоп 1, Б9-1 }\end{array}$ & - \\
\hline 18 & Обойма & б/и & $\begin{array}{l}\text { Царевское городище - 1996, } \\
\text { раскоп 1, Б5-5 }\end{array}$ & - \\
\hline 19 & Клепка & б/и & $\begin{array}{l}\text { Царевское городище - 1994, } \\
\text { раскоп } 1, \text { Д10-2 }\end{array}$ & {$[5$, c. 46$]$} \\
\hline 20 & Бубенчик & $14257 / 1$ & $\begin{array}{l}\text { Водянское городище - } 1972, \\
\text { раскоп } 3 \text {, дом } 1\end{array}$ & - \\
\hline 21 & Крест (фрагмент) & $14257 / 3$ & $\begin{array}{l}\text { Водянское городище - } 1972, \\
\text { раскоп } 2, \text { яма } 38\end{array}$ & - \\
\hline 22 & Грузик & $14257 / 36$ & $\begin{array}{l}\text { Водянское городище - } 1972, \\
\text { раскоп } 2, \text { землянка }\end{array}$ & - \\
\hline 23 & Браслет (фрагмент) & $14266 / 9$ & $\begin{array}{l}\text { Водянское городище - } 1969, \\
\text { раскоп } 1, \text { яма } 6\end{array}$ & - \\
\hline 24 & Обойма & $14257 / 52$ & $\begin{array}{l}\text { Водянское городище - 1972, } \\
\text { уч. } 38\end{array}$ & - \\
\hline 25 & Гвоздик-〈костыль» & $14257 / 48$ & $\begin{array}{l}\text { Водянское городище - } 1972, \\
\text { раскоп } 2, \text { яма } 38\end{array}$ & - \\
\hline 26 & Чаша (фрагмент) & $14263 / 20$ & Водянское городище - 1969 & - \\
\hline 27 & $\begin{array}{l}\text { Изделие в виде палочки с } \\
\text { загнутыми концами }\end{array}$ & б/и & $\begin{array}{l}\text { Царевское городище - 1995, } \\
\text { раскоп 1, 4-Б4 }\end{array}$ & - \\
\hline 28 & Заготовка браслета & б/и & $\begin{array}{l}\text { Царевское городище - } 1995, \\
\text { раскоп 1, 4-В6 }\end{array}$ & {$[5$, c. $80-81]$} \\
\hline
\end{tabular}


К.С. Ковалева. Результаты исследования техники изготовления золотоордынских изделий

Продолжение таблиць

\begin{tabular}{|c|c|c|c|c|}
\hline $\begin{array}{l}\text { № } \\
\Pi / \Pi\end{array}$ & Наименование & $\begin{array}{l}\text { Шифр } \\
\text { хранения } \\
\text { ВОКМ }\end{array}$ & Происхождение & Публикации \\
\hline 29 & Зеркало (фрагмент) & б/и & $\begin{array}{l}\text { Царевское городище - } 1995, \\
\text { раскоп 1, 4-Б1 }\end{array}$ & - \\
\hline 30 & Зеркало (фрагмент) & $10390 / 8$ н/в & $\begin{array}{l}\text { Водянское городище - 2012, } \\
\text { раскоп } 1,2-16 \mathrm{E}\end{array}$ & {$[8$, c. 69,209$]$} \\
\hline 31 & Обойма (наперсток) & $33747 / 1$ & $\begin{array}{l}\text { Водянское городище - 2012, } \\
\text { раскоп } 1,1-13 \mathrm{~B}\end{array}$ & {$[8$, c. 62,209$]$} \\
\hline 32 & Зеркало (фрагмент) & $\begin{array}{c}10390 / 36 \\
\mathrm{H} / \mathrm{B}\end{array}$ & $\begin{array}{l}\text { Водянское городище - 2012, } \\
\text { раскоп } 1,2-17 \text { А }\end{array}$ & {$[8$, c. 69,209$]$} \\
\hline 33 & Заготовка & $\begin{array}{c}10390 / 117 \\
\mathrm{H} / \mathrm{B}\end{array}$ & $\begin{array}{l}\text { Водянское городище - 2012, } \\
\text { раскоп 1, подъемный } \\
\text { материал }\end{array}$ & {$[8$, c. 51,208$]$} \\
\hline 34 & Пряжка & $14260 / 10$ & $\begin{array}{l}\text { Водянское городище, } \\
\text { подъемный материал }\end{array}$ & - \\
\hline 35 & Зеркало & $10390 / 6 \mathrm{H} / \mathrm{B}$ & $\begin{array}{l}\text { Водянское городище - 2012, } \\
\text { раскоп } 1,1-17 \mathrm{E}\end{array}$ & $\begin{array}{l}{[8, \text { c. } 61-62} \\
209]\end{array}$ \\
\hline 36 & Зеркало (фрагмент) & $10390 / 5$ н/в & $\begin{array}{l}\text { Водянское городище - 2012, } \\
\text { раскоп } 1,1-17 \Gamma\end{array}$ & {$[8$, c. 61,209$]$} \\
\hline 37 & Зеркало (фрагмент) & $\begin{array}{c}10390 / 87 \\
\mathrm{H} / \mathrm{B}\end{array}$ & $\begin{array}{l}\text { Водянское городище - } 2012, \\
\text { раскоп } 1, \text { яма } 38\end{array}$ & {$[8$, c. 77,209$]$} \\
\hline 38 & Пуговицы (3 шт.) & $14260 / 14$ & $\begin{array}{l}\text { Водянское городище - } 1973, \\
\text { раскоп 2, 4-43 }\end{array}$ & - \\
\hline 39 & Пластина (фрагмент) & $6156 / 18$ & $\begin{array}{l}\text { Царевское городище - } 1963, \\
\text { раскоп } 6, \text { яма } 1\end{array}$ & - \\
\hline 40 & Зеркало (фрагмент) & $24053 / 27$ & $\begin{array}{l}\text { Водянское городище - 1974, } \\
\text { раскоп 2, 3-17 }\end{array}$ & - \\
\hline 41 & Зеркало (фрагмент) & 5987 & $\begin{array}{l}\text { Царевское городище - 1962, } \\
\text { раскоп 3, 45-2 }\end{array}$ & - \\
\hline 42 & Зеркало (фрагмент) & $15 /-$ & $\begin{array}{l}\text { Царевское городище - 1962, } \\
\text { подъемный материал }\end{array}$ & - \\
\hline 43 & Зеркало (фрагмент) & $24054 / 1$ & $\begin{array}{l}\text { Водянское городище - 1972, } \\
\text { раскоп 2, 4-384 }\end{array}$ & - \\
\hline 44 & Зеркало (фрагмент) & 5991 & $\begin{array}{l}\text { Царевское городище - 1962, } \\
\text { подъемный материал }\end{array}$ & - \\
\hline 45 & Зеркало (фрагмент) & б/и & $\begin{array}{l}\text { Водянское городище - 1968, } \\
\text { подъемный материал }\end{array}$ & - \\
\hline 46 & Зеркало (фрагмент) & $33459 / 9$ & $\begin{array}{l}\text { Водянское городище - } 2010, \\
\text { раскоп } 1, \text { яма } 28\end{array}$ & $\begin{array}{c}{[7, \mathrm{c} 61,146-} \\
147]\end{array}$ \\
\hline 47 & Зеркало & $424104 / 21$ & $\begin{array}{l}\text { Мечетное городище - } 1986, \\
\text { подъемный материал }\end{array}$ & - \\
\hline 48 & Накладка & $33459 / 4$ & $\begin{array}{l}\text { Водянское городище - 2010, } \\
\text { раскоп } 1,2-7 \mathrm{E}\end{array}$ & {$[7$, c. 35$]$} \\
\hline 49 & Перстень & $14260 / 11$ & $\begin{array}{l}\text { Водянское городище - } 1973, \\
\text { подъемный материал }\end{array}$ & - \\
\hline 50 & Пряжка & $14260 / 20$ & $\begin{array}{l}\text { Водянское городище - 1973, } \\
\text { подъемный материал }\end{array}$ & - \\
\hline 51 & Оковка & $14260 / 30$ & $\begin{array}{l}\text { Царевское городище - 1973, } \\
\text { раскоп 1, 3-81 }\end{array}$ & - \\
\hline 52 & Астрагал & $14260 / 27$ & $\begin{array}{l}\text { Водянское городище - 1973, } \\
\text { подъемный материал }\end{array}$ & - \\
\hline 53 & Чаша (фрагмент) & $14260 / 13$ & Водянское городище - 1973 & - \\
\hline 54 & $\begin{array}{l}\text { Гигиенический набор } \\
\text { (копоушка и зубочистка) }\end{array}$ & 14260 & Водянское городище - 1973 & - \\
\hline 55 & Пуговица (накладка) & $14260 / 17$ & Водянское городище - 1973 & - \\
\hline
\end{tabular}


Окончание таблицьь

\begin{tabular}{|c|c|c|c|c|}
\hline $\begin{array}{l}\text { № } \\
\Pi / \Pi\end{array}$ & Наименование & $\begin{array}{c}\text { Шифр } \\
\text { хранения } \\
\text { ВОКМ }\end{array}$ & Происхождение & Публикации \\
\hline 56 & Изделие & $14260 / 21$ & $\begin{array}{l}\text { Водянское городище - 1973, } \\
\text { раскоп 2, 3-64 }\end{array}$ & - \\
\hline 57 & Обойма & $14260 / 23$ & Водянское городище - 1973 & - \\
\hline 58 & $\begin{array}{l}\text { Серьга в виде знака } \\
\text { «вопрос» }\end{array}$ & $14260 / 24$ & Водянское городище - 1973 & - \\
\hline 59 & $\begin{array}{l}\text { Изделие (фибула?; } \\
\text { фрагмент) }\end{array}$ & $14260 / 15$ & Водянское городище - 1973 & - \\
\hline 60 & Наконечник ремня & $14260 / 26$ & $\begin{array}{l}\text { Водянское городище - 1973, } \\
\text { раскоп } 2\end{array}$ & - \\
\hline 61 & Перстень с жемчугом & 14260 & $\begin{array}{l}\text { Водянское городище - 1973, } \\
\text { раскоп 2, 4-43 }\end{array}$ & - \\
\hline 62 & Бубенец & 14260 & $\begin{array}{l}\text { Водянское городище }-1973, \\
\text { раскоп 2, 2-58 }\end{array}$ & - \\
\hline 63 & Изделие (фрагмент) & $14260 / 22$ & $\begin{array}{l}\text { Водянское городище - } 1973, \\
\text { подъемный материал }\end{array}$ & - \\
\hline
\end{tabular}

\section{ПРИМЕЧАНИЯ}

${ }^{1}$ Работа выполнена в рамках государственного задания Минобрнауки РФ (проект № 33.2830.2017/4.6 «Юг России в эпоху раннего железного века: диалог культур Восток - Запад»).

${ }^{2}$ Выражаю благодарность сотрудникам и руководству Волгоградского областного краеведческого музея, а также авторам полевых работ Ю.А. Зеленееву, Е.П. Мыськову, А.С. Лапшину и А.А. Глухову за предоставленную возможность ознакомиться с материалами и провести исследование.
${ }^{3}$ Методические основы трасологического метода для изучения археологического цветного металла разработаны Н.В. Рындиной [10, с. 201-203], основные принципы конкретизированы в работах Н.В. Ениосовой и Т.Г. Сарачевой [3; и др.]; способы проведения исследования трасологическим методом опубликованы А.Д. Дегтяревой [2].

${ }^{4}$ Выражаю признательность И.А. Сапрыкиной (ИА РАН) за консультации и помощь в проведении анализа.

${ }^{5}$ Номер вещи по каталогу соответствует номеру позиции на рисунке 1. 


\section{ПРИЛОЖЕНИЕ}
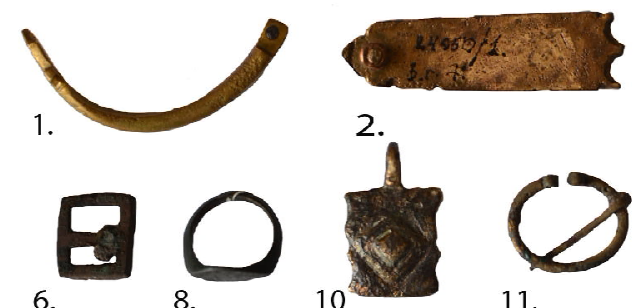

8.

6.

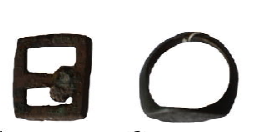

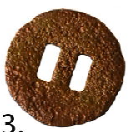

3.

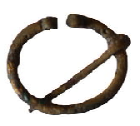

11.

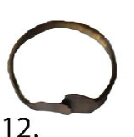

12.

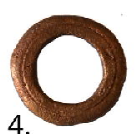

8.

5.

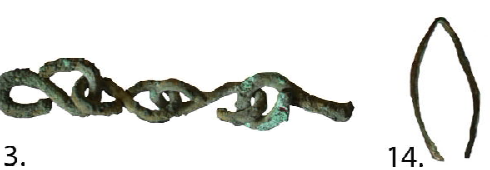

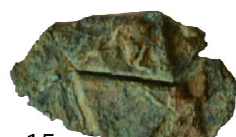

15.

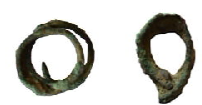

16.

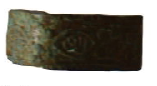

18.

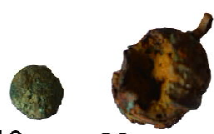

19.

20.

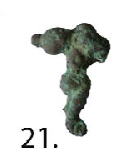

22.
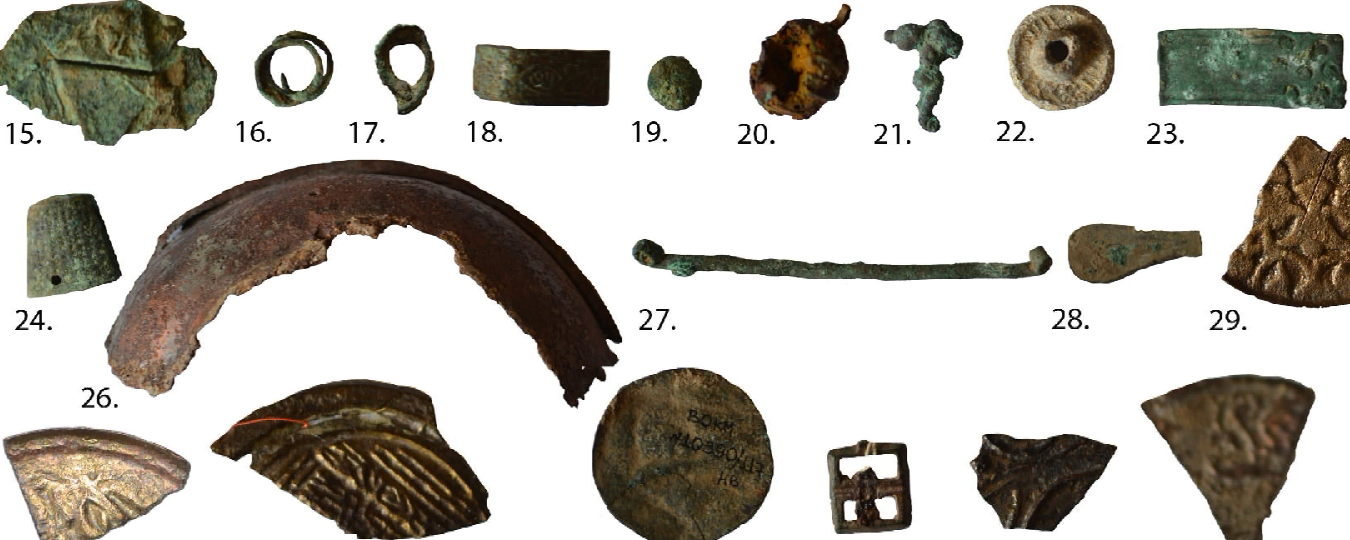

32.

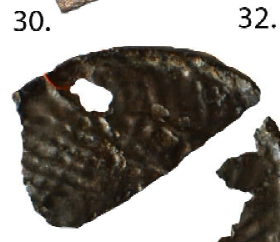

37.

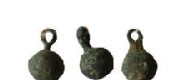

33.
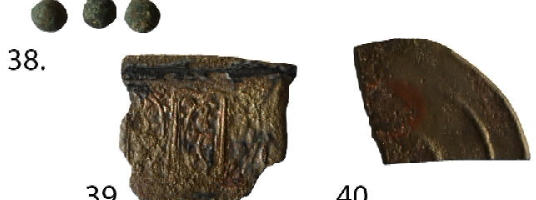

40.

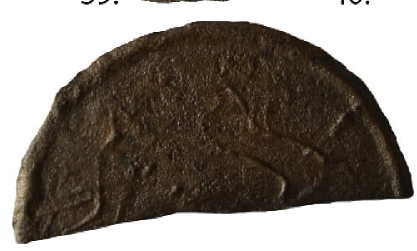

45.
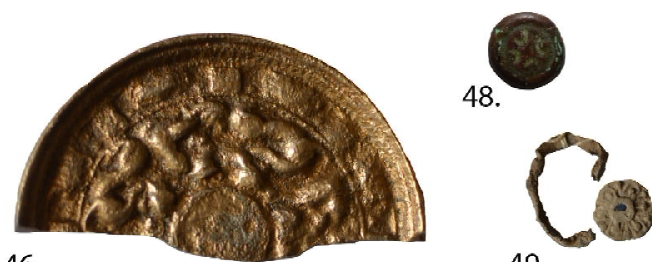

44.

46.

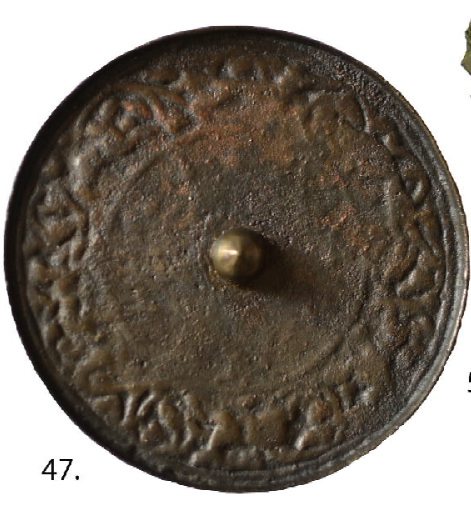

minlmanسm
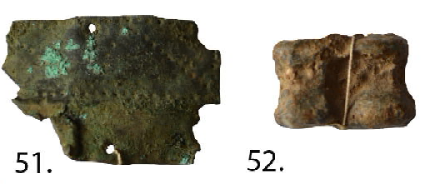

52.
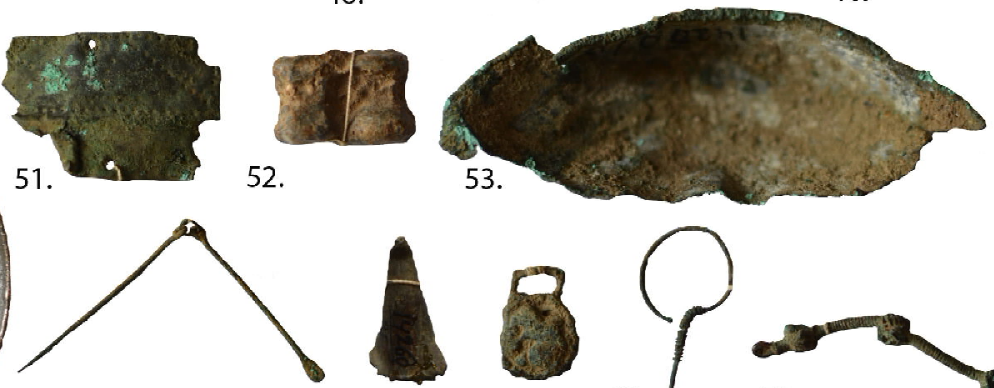

56.

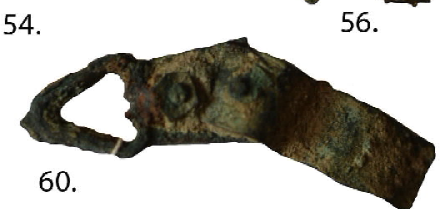

57.

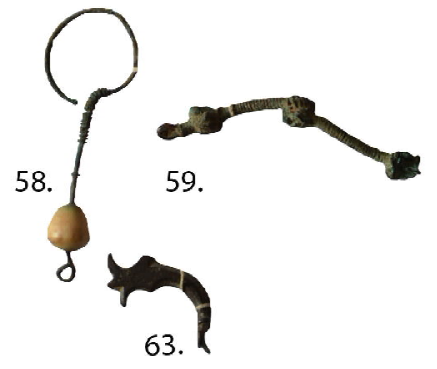

Рис. 1. Изделия из цветных металлов из коллекции Волгоградского областного краеведческого музея

Fig. 1. The products made of non-ferrous metals from the collection of the Volgograd regional museum of local lore 


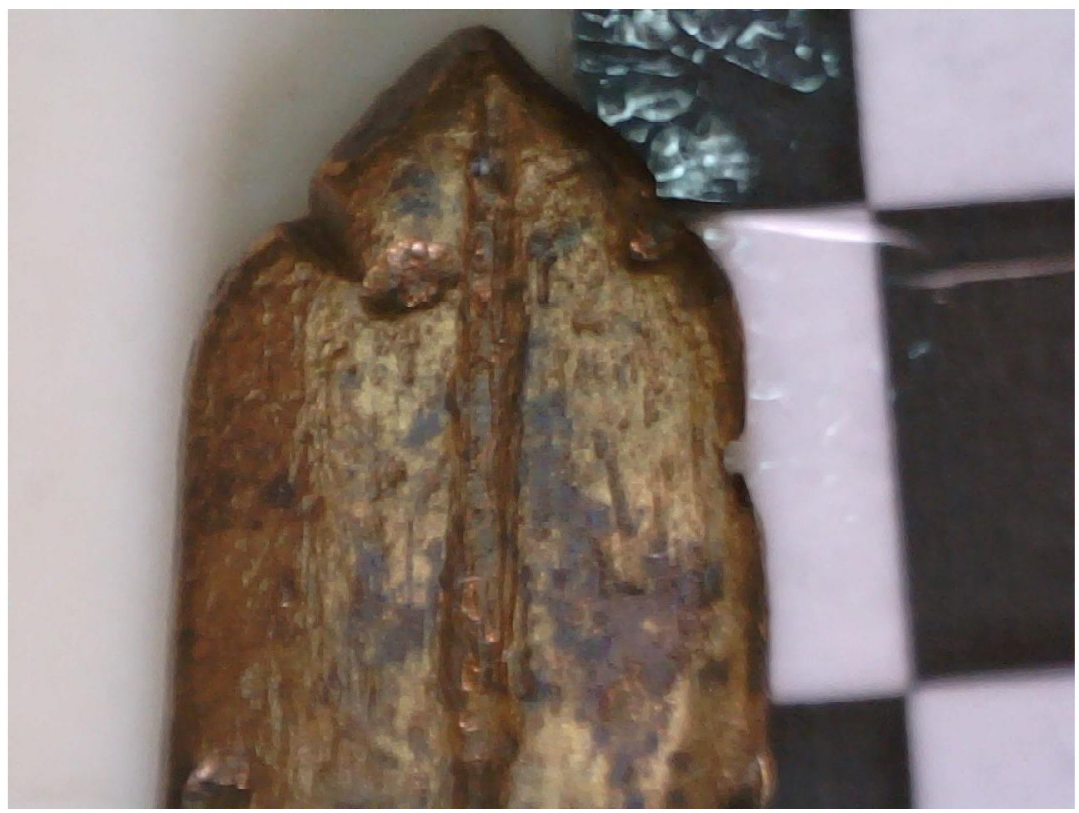

$a$

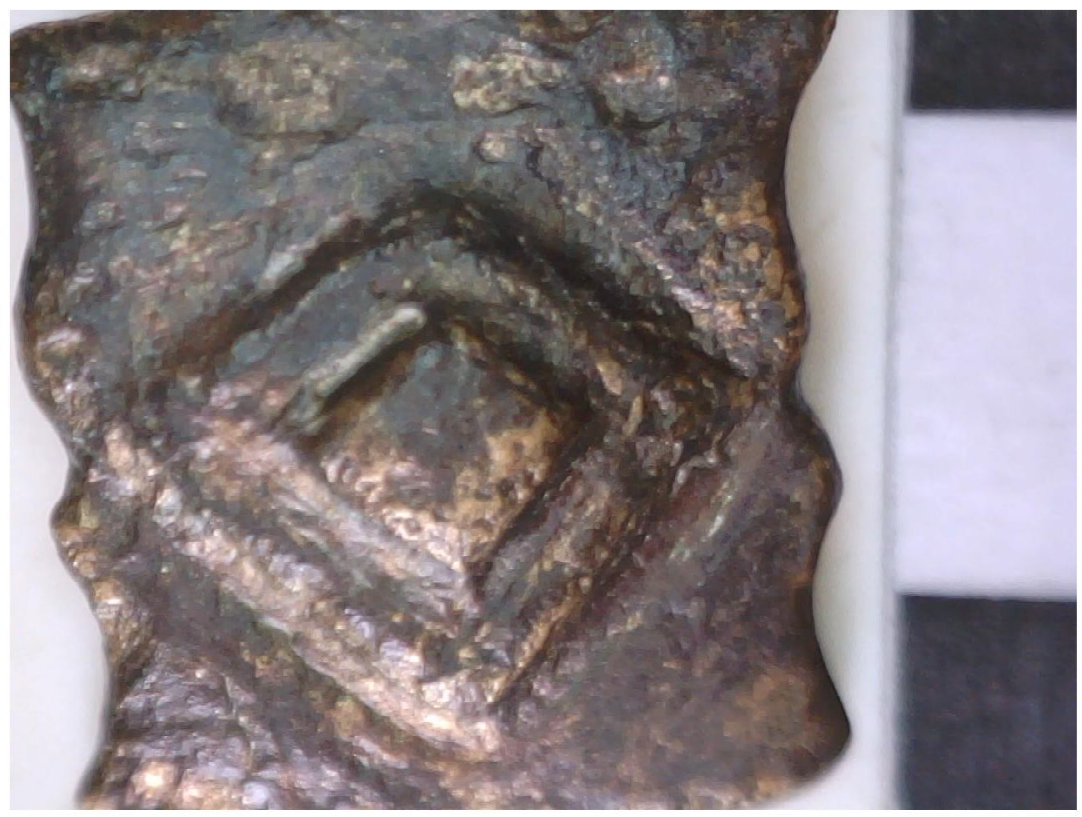

$\sigma$

Рис. 2. Смазанный рельеф основных частей изделия при литье по оттиску: $a$ - наконечник ремня; $\sigma$ - бляшка

Fig. 2. Blurry relief of the main parts of the product during casting by imprint $a$ - belt head; $\sigma$ - buckle 
К.С. Ковалева. Результаты исследования техники изготовления золотоордынских изделий

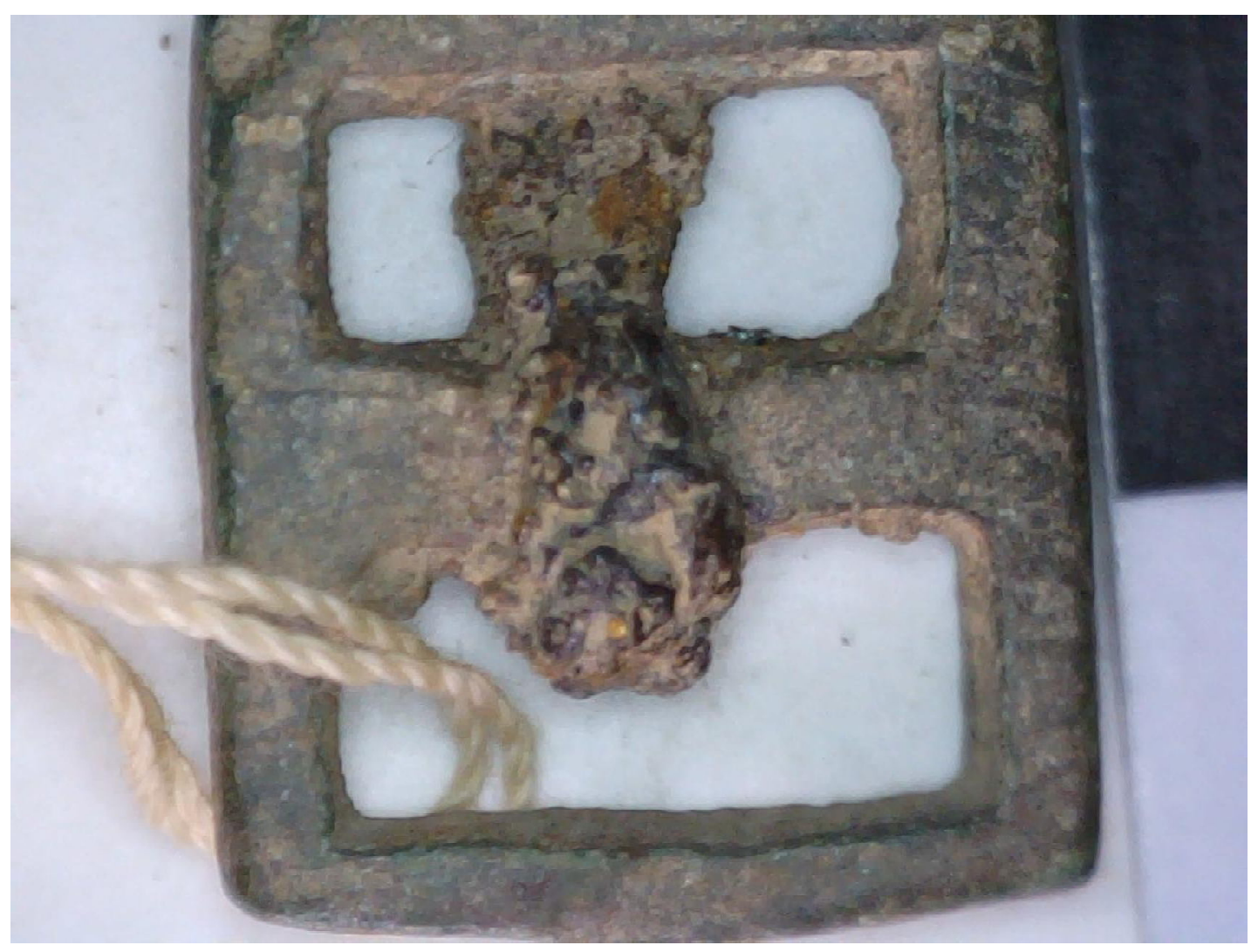

Рис. 3. Частично сохранившиеся следы литейного шва на пряжке

Fig. 3. Partially preserved traces of the casting seam on the buckle 


\section{АРХЕОЛОГИЯ}

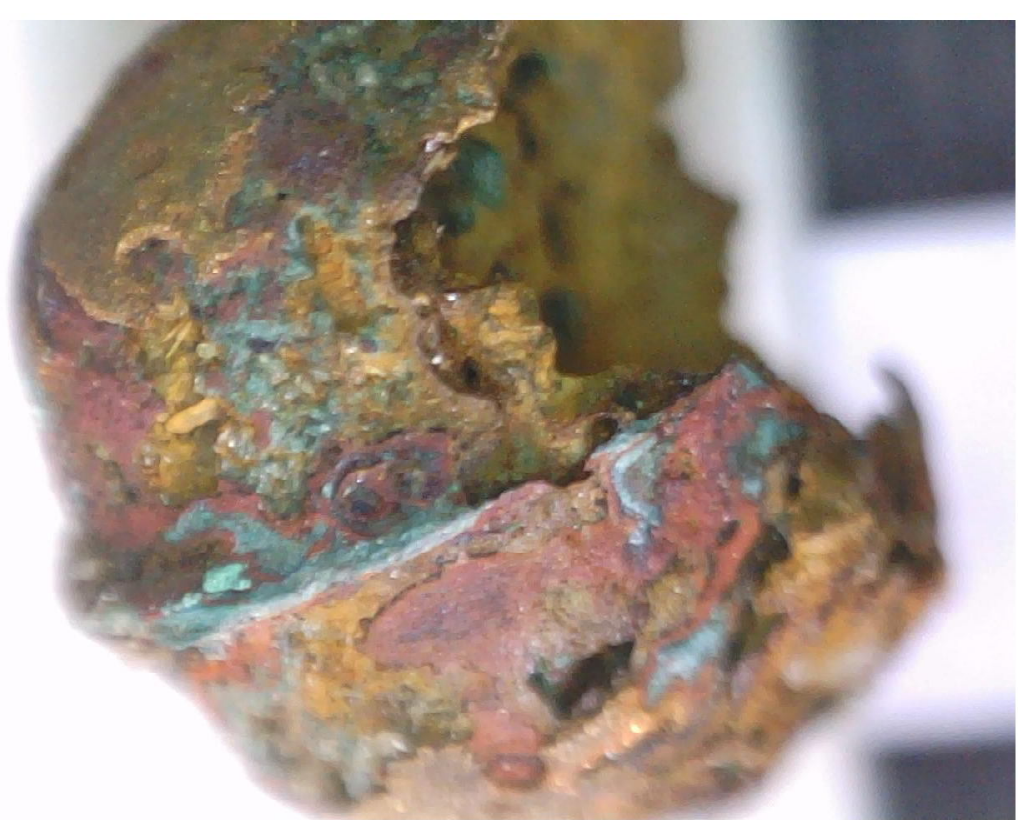

$a$

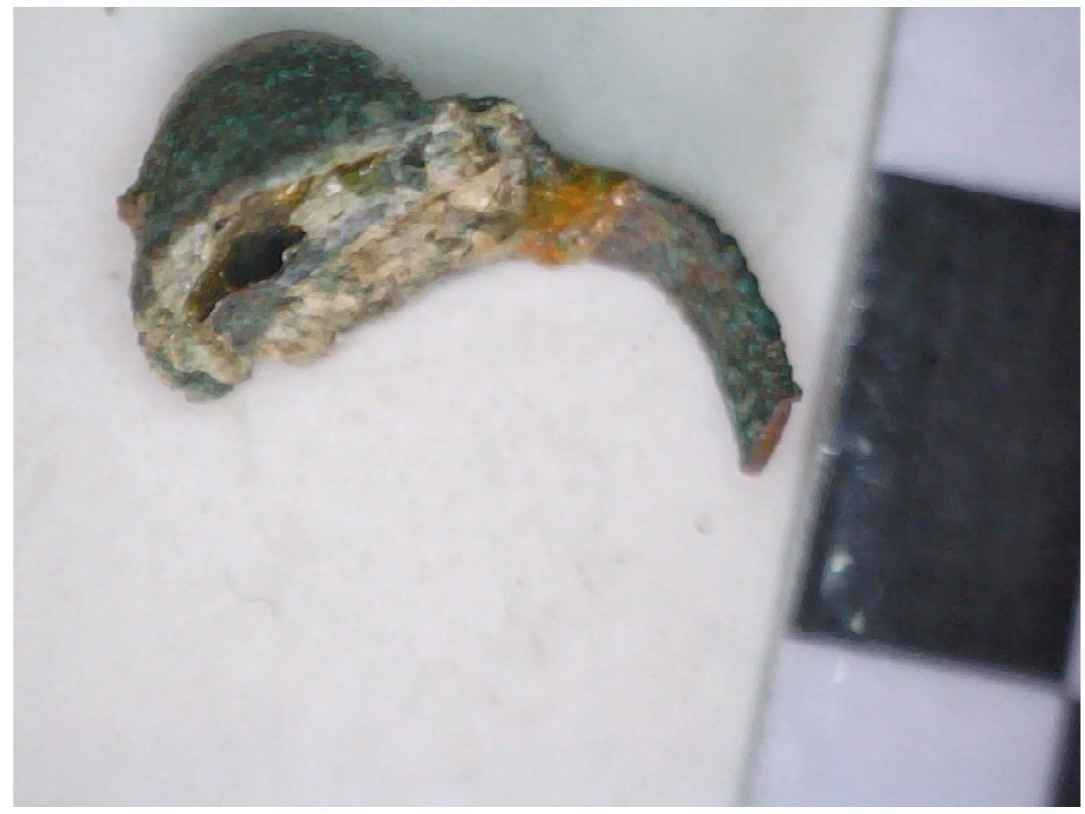

б

Рис. 4. Пайка:

$a$ - спаянные половинки бубенчика; $\sigma$ - каст, припаянный к щитку перстня

Fig. 4. Soldering:

$a$ - soldered halves of the jingle; $\sigma$ - cast soldered to the shield of ring 


\section{СПИСОК ЛИТЕРАТУРЫ}

1. Блохин, В. Г. Археология золотоордынских городов Нижнего Поволжья : учеб. пособие / В. Г. Блохин, Л. В. Яворская. - Волгоград : Изд-во ВолГУ, 2006. -268 с.

2. Дегтярева, А. Д. Методика поверхностного изучения цветного металла / А. Д. Дегтярева // Вестник археологии, антропологии и этнографии. - 2006. - № 6. - С. 117-126.

3. Ениосова, Н. В. Средневековое ювелирное ремесло Европы : Основные аспекты в истории изучения / Н. В. Ениосова, Т. Г. Сарачева // Древности Евразии. - М. : Изд-во МГУ, 1997. - С. 286-309.

4. Зайцева, И. Е. Ювелирное дело «Земли вятичей» второй половины XI-XIII в. / И. Е. Зайцева, Т. Г. Сарачева. - М. : Индрик, 2011. -404 с.

5. Зеленеев, Ю. А. Золотоордынский город Сарай-ал-Джедид (результаты археологических исследований на Царевском городище в 1994-2000 гг.) / Ю. А. Зеленеев, С. А. Курочкина. - Йошкар-Ола : Изд-во МарГУ, 2009. - 264 с.

6. Ильина, О. А. Мечетное городище / О. А. Ильина // Нижневолжский археологический вестник. -2005. - Вып. 7. - С. 103-113.

7. Лапшин, А. С. Исследования на Водянском городище в 2009-2010 гг. / А. С. Лапшин, Е. П. Мыськов. - Волгоград : Царицын. полигр. компания, 2011. - $172 \mathrm{c.}$

8. Лапшин, А. С. Исследования на Водянском городище в 2011-2012 гг. / А. С. Лапшин, Е. П. Мыськов. - Волгоград ; М. : Перо, 2013. - 215 с.

9. Рыбаков, Б. А. Ремесло Древней Руси / Б. А. Рыбаков. - М. : Изд-во АН СССР, 1948. - 792 с.

10. Рындина, Н. В. Технология производства новгородских ювелиров X-XV вв. / Н. В. Рындина // Материалы и исследования по археологии CCCP. - 1963. - № 117. - С. 200-247.

11. Терещенко, А. В. Археологические поиски в развалинах Сарая / А. В. Терещенко // Записки Санкт-Петербургского археолого-нумизматического общества. - СПб. : [б. и.], 1850. - Т. 2. C. 310-364.

12. Флеров, А. В. Материаловедение и технология художественной обработки металлов / А. В. Флеров. - М. : Высш. шк., 1981. -288 с.

\section{REFERENCES}

1. Blokhin V.G., Yavorskaya L.V. Arkheologiya zolotoordynskikh gorodov Nizhnego Povolzhya
[Archaeology of Golden Horde's Cities of the Lower Volga Region]. Volgograd, Izd-vo VolGU, 2006. 268 p.

2. Degtyareva A.D. Metodika poverkhnostnogo izucheniya tsvetnogo metalla [The Method of Surface Study of Non-Ferrous Metal]. Vestnik arkheologii, antropologii i etnografii, 2006, no. 6, pp. 117-126.

3. Eniosova N.V., Saracheva T.G. Srednevekovoe yuvelirnoe remeslo Evropy: Osnovnye aspekty v istorii izucheniya [Medieval European Jewelcraft: the Main Aspects of the History of Studies]. Drevnosti Evrazii. Moscow, Izd-vo MGU, 1997, pp. 286-309.

4. Zaytseva I.E., Saracheva T.G. Yuvelirnoe delo "Zemli vyatichey» vtoroy poloviny XI - XIII v. [Jeweler's Craft of "Land of Vyatichi" in the Second Half of the $11^{\text {th }}-13^{\text {th }}$ Centuries]. Moscow, Indrik Publ., 2011. 404 p.

5. Zeleneev Yu.A., Kurochkina S.A. Zolotoordynskiy gorod Saray-al-Dzhedid (rezultaty arkheologicheskikh issledovaniy na TSarevskom gorodishche v 1994-2000 gg.) [The Golden Horde City of Saray-al-Jedid (the Results of Archaeological Research in the Tsarevskoe Settlement in 1994-2000)]. Yoshkar-Ola, Izd-vo MarGU, 2009. 264 p.

6. Ilyina O.A. Mechetnoe gorodishche[The Mosque Settlement]. Nizhnevolzhskiy arkheologicheskiy vestnik [The Lower Volga Archaeological Bulletin], 2005, vol. 7, pp. 103-113.

7. Lapshin A.S., Myskov E. P. Issledovaniya na Vodyanskom gorodishche v 2009-2010 gg. [Research in the Vodyanskoe Settlement in 2009-2010]. Volgograd, Tsaritsyn. poligr. kompaniya, 2011. 172 p.

8. Lapshin A.S., Myskov E. P. Issledovaniya na Vodyanskom gorodishche v 2011-2012 gg. [Research in the Vodyanskoe Settlement in 2011-2012]. Volgograd; Moscow, Pero Publ., 2013. 215 p.

9. Rybakov B.A. Remeslo Drevney Rusi [Craft of Ancient Rus]. Moscow, Izd-vo AN SSSR, 1948. 792 p.

10. Ryndina N.V. Tekhnologiya proizvodstva novgorodskikh yuvelirov $\mathrm{X}-\mathrm{XV}$ vv. [Production Technology of Novgorod Jewelers in the $10^{\text {th }}-15^{\text {th }}$ Centuries]. Materialy $i$ issledovaniya po arkheologii SSSR, 1963, no. 117, pp. 200-247.

11. Tereshchenko A.V. Arkheologicheskie poiski $\mathrm{v}$ razvalinakh Saraya [Archaeological Searches in the Ruins of Saray]. Zapiski sankt-peterburgskogo arkheologo-numizmaticheskogo obshchestva, 1850, vol. 2, pp. 310-364.

12. Flerov A.V. Materialovedenie i tekhnologiya khudozhestvennoy obrabotki metallov [Materials Science and Technology of Artistic Processing of Metals]. Moscow, Vysshaya shkola Publ., 1981. 288 p. 


\section{Information about the Author}

Kseniya S. Kovaleva, Postgraduate Student, Institute of Archaeology, RAS, Dm. Ulyanova St., 19, 117036 Moscow, Russian Federation; Researcher of Laboratory of Archaeological Research, Volgograd State University, Prosp. Universitetsky, 100, 400062 Volgograd, Russian Federation, ksenmorgan@gmail.com, kovaleva@volsu.ru, https://orcid.org/0000-0002-5429-1072

\section{Информация об авторе}

Ксения Сергеевна Ковалева, аспирант, Институт археологии РАН, ул. Дм. Ульянова, 19, 117036 г. Москва, Российская Федерация; научный сотрудник лаборатории археологических исследований, Волгоградский государственный университет, просп. Университетский, 100, 400062 г. Волгоград, Российская Федерация, ksenmorgan@gmail.com, kovaleva@volsu.ru, https://orcid.org/ 0000-0002-5429-1072 